\title{
ПАРЛАМЕНТСКИЕ ВЫБОРЫ 2018 ГОДА В АРМЕНИИ: ПЕРСПЕКТИВЫ БЛОКА «МОЙ ШАГ»
}

\begin{abstract}
Аннотация. 9 декабря 2018 г. в Армении прошли досрочные парламентские выборы, завершившие прочесс смень власти, начавшийся в апреле того же года. В результате Республиканская партия Армении из доминирующей политической силь перешла в статус внепарламентской оппозищии. Победу на выборах одержал блок «Им кайл» («Мой шаг»), основанный лидером массовых протестов - Николом Пашиняном. Произошедшая политическая трансформация тем не менее лишь обострила стоящие перед Арменией вопросы реформирования политических институтов, почска экономической стратегии развития, решения нагорнокарабахского вопроса.
\end{abstract}

Ключевые слова: Армения, парламентские выборы.

\section{Революция или смена власти?}

В апреле 2018 г. в Армении в ходе массовых мирных протестов была осуществлена смена власти, в результате которой пост премьер-министра занял представитель оппозиции, ранее депутат Национального собрания Армении, журналист, общественный деятель, активист Никол Пашинян. Логической точкой в этом процессе стали досрочные парламентские выборы, состоявшиеся 9 декабря 2018 г. Таким образом, был завершён процесс перехода к парламентской республике, инициированный ранее правящей Республиканской партией Армении (РПА). Для РПА реформа ознаменовала попытку в очередной раз удержать власть и пост премьер-министра в своих руках. Она тем не менее завершилась провалом - несмотря на ожидания в самой партии.

События 2018 г. произошли вопреки тенденции к консолидации власти. Его начало следует отнести к 2008 г., когда третьим президентом Армении был избран представитель Республиканской партии Армении Серж Саргсян, продолживший курс Роберта Кочаряна. Выборы привели к массовым протестам, введению чрезвычайного положения в стране, гибели десяти человек в ходе насильственного подавления демонстрации. Именно расследование событий 1 марта 2008 г., когда произошло столкновение демонстрантов и полиции, стало знаковым для пришедшего к власти Н. Пашиняна. Новым правительством предпринята попытка маркировать преступный характер прежней власти. Главным шагом к этому стал арест Роберта Кочаряна по обвинению в свержении конституционного строя страны в 2008 г. То же обвинение предъявлено Юрию Хачатурову, занимающему пост генерального секретаря ОДКБ.

Можно ли обозначить осуществившуюся смену политической элиты страны как революцию? Вероятно, на этот вопрос пока не может быть ответа. Процесс политической трансформации был запущен, но его содержание не до конца ясно. Высок риск нестабильности и череды попыток вернуть власть. Вопрос о том, как долго просуществует избранный парламент, был включён в повестку предвыборных дебатов. Ответ на него будет зависеть от того,

(C) Айвазян Анна Степановна - научный сотрудник Отдела европейской интеграции ИЕ РАН. Адрес: 125009 , Россия, Москва, ул. Моховая, д. 11, стр. 3. E-mail: anna.ayvazyan@gmail.com.

DOI: http://dx.doi.org/10.15211/vestnikieran620186164 
насколько действующая власть сможет обеспечить функционирование политических институтов, когда ресурс поддержки со стороны толпы снизится и возникнет необходимость продуманной долгосрочной стратегии. При этом избранное правительство и парламент столкнутся с ожиданиями воодушевлённого революцией населения, ждущего ощутимых результатов уже в ближайшее время.

\section{Результаты выборов. Роль политической оппозиции}

В сложившейся ситуации опасение вызывают несколько факторов. Среди них - персонализация протеста вокруг личности Никола Пашиняна, поляризация политического поля, где политическое мнение выражается в рамках противостояния сторонников Пашиняна с представителями РПА. Подобное обвинение в адрес премьер-министра раздаётся не только со стороны его прямых оппонентов из РПА, кроме всего прочего заявляющих о некомпетентности команды Пашиняна, популизме, отсутствии у новой политической силы ясной идеологии. Во время предвыборных дебатов на общественном телевидении Сурен Саакян, лидер политической партии «Кахакацу ворошум» («Решение гражданина») обратился к премьер-министру с заявлением о его личной ответственности за создание ситуации, когда голосование против Пашиняна означает безусловную поддержку РПА ${ }^{1}$.

Таким образом, перед блоком «Им кайл» («Мой шаг»), основанным Н. Пашиняном, встала задача определить рамки и правила дальнейшей игры. Несмотря на то, что в 2018 г. политическая риторика внутри Армении развивалась в логике существования «чёрного» и «белого», неизбежен вопрос о допущении главного политического оппонента в лице РПА к участию в принятии решений. По итогам прошедших выборов Республиканская партия не прошла 5\%-ный барьер, набрав 4,7\% голосов, что равно 59083 голосам избирателей. У блока «Мой шаг» 88 из 132 мест в парламенте (70,42\% голосов). Остальные места поделены между «Процветающей Арменией» $\left(8,26 \%\right.$ голосов) и «Просвещённой Арменией» $(6,37 \% \text { голосов })^{2}$. Этот результат означает переход РПА во внепарламентскую оппозицию, а для блока «Им кайл» - отсутствие какого-либо существенного противовеса, а также риск исчерпания ресурса народной поддержки и личной привлекательности фигуры Н. Пашиняна.

Во избежание повторной монополизации политической сферы одной партией возрастает роль потенциального критика Пашиняна и блока «Им кайл». Им, судя по высказываниям в СМИ и в ходе предвыборных дебатов, станет партия «Просвещённая Армения», лидер которой Эдмон Марукян неоднократно выступал с негативной оценкой нового правительства и блока «Им кайл». Этот факт в особенности интересен тем, что партия «Просвещённая Армения» ранее входила в избирательный блок «Елк» совместно с партией «Гражданский договор», основанной Н. Пашиняном и составившей костяк нового блока «Им кайл».

Один из основных аргументов Э. Марукяна - слияние бизнеса и политики в новой Армении. Он подчёркивает предполагаемую неразборчивость Пашиняна в выборе соратников и неприемлемость присутствия лояльной к РПА партии «Процветающая Армения» в избранном парламенте ${ }^{3}$. Лидер партии - Гагик Царукян, крупнейший армянский бизнесмен.

\section{Политическая повестка блока «Им кайл»: основные проблемные вопросы}

Антикоррупционная программа и обеспечение экономической конкуренции - главный акцент политической программы партии «Гражданский договор», на основе которой сформи-

\footnotetext{
${ }^{1}$ Armenia's Parliamentary Debate. CivilNet. URL: https://www.civilnet.am/live/C907_SyKkiI/494 дата обращения: 23.12.2018).

December 09, 2018 Parliamentary Elections. Central Electoral Commission. URL: https://www.elections.am/ parliamentary/ (дата обращения: 23.12.2018).

${ }^{3}$ Бывший соратник дата обращения: 23.12.2018).
}

Научно-аналитический вестник ИЕ РАН, 2018, №6 
рован блок «Им кайл». Приход к власти Н. Пашиняна был ознаменован чередой крупных антикоррупционных дел против бизнесменов, аффилированных с прежней властью. Некоторые из них приняли решение пойти на сделку с новым правительством: так, в СМИ появилась новость о том, что брат бывшего президента Армении Александр Саргсян согласился передать в бюджет страны 30 млн долл., а бывший глава таможенного комитета Армен Аветисян хочет передать государству свою гостиницу стоимостью 20 млн долл. ${ }^{1}$

Используя ресурс общественной поддержки в борьбе с монополизацией экономики, премьер-министр Армении пообещал избирателям в 2019 г. повышение пенсий и зарплат, увеличение социальных выплат, улучшение условий кредитования ${ }^{2}$. Государственный бюджет планируется пополнять за счёт дохода от перевода теневой экономики в легальное поле. Очевидно, что этот источник ограничен, а речи о структурных экономических реформах пока не идёт. Тем не менее, программа партии «Гражданский договор» упоминает о необходимости развития малого и среднего бизнеса, применении инноваций и высоких технологий в сельском хозяйстве, промышленности, государственном управлении и др. ${ }^{3}$

Ещё одно предвыборное обещание блока «Им кайл» - снижение цены на российский газ. Тем не менее, несмотря на то, что переговоры с Россией по этому поводу были начаты, решение вряд ли будет принято в скором времени ${ }^{4}$.

Инициирование множества уголовных дел также поставило вопрос осуществления правосудия в переходный период, что стало предметом обсуждения кандидатов во время предвыборных дебатов. С одной стороны, понятно намерение новой власти завершить предшествующий период армянской государственности. С другой стороны, публичное осуждение прежнего политического режима стало основным инструментом построения избирательной компании блока «Им кайл», а тонкая грань между торжеством правосудия и политически мотивированными преследованиями оппонентов может быть легко нарушена.

Перед новым парламентом по-прежнему будет стоять задача решения нагорно-карабахского вопроса. Предвыборные дебаты показали, что среди политических сил Армении нет консенсуса о том, каким образом следует обсуждать карабахскую проблему. Так, например, политическая партия «Сасна црер», представленная в том числе ветеранами карабахской войны, заявляет о том, что Арцах (Нагорный Карабах) следует рассматривать как ещё одну армянскую провинцию. Для г-на Царукяна вопрос Нагорного Карабаха уже решён армянским народом, и единственное, что требуется - признание этого со стороны международного сообщества. С другой стороны, Н. Пашинян придерживается позиции, согласно которой решение должно быть принято народом Армении и Нагорного Карабаха. Вместе с тем, политик утверждает, что не следует ожидать от Армении компромиссов ни в какой ситуации: так же, как никто не ожидает компромисса от азербайджанской стороны ${ }^{5}$. В этой ситуации растёт критика продажи оружия со стороны России Азербайджану, что подрывает доверие к России как к действительно надёжному партнёру. В целом, следует ожидать более твёрдой и прямолинейной позиции Армении по вопросам сотрудничества с Россией: как в вопросе экономического, так и военно-политического взаимодействия.

\footnotetext{
1 Пашинян анонсировал пополнение бюджета Армении деньгами олигархов. Кавказский узел. URL: https://www.kavkaz-uzel.eu/articles/328518/ (дата обращения: 23.12.2018).

2 Пашинян пообещал повысить зарплаты. News.am. URL: https://news.am/rus/news/483580.html (Дата обращения: 23.12.2018).

Slu unt u n L קJ n L U. Civic Contract. URL: https://civilcontract.am/party-program/tntesowt-уown (дата обращения: 23.12.2018).

4 Пашинян и Путин пока не смогли договориться о цене на российский газ. REGNUM. https://regnum.ru/ news/2537590.html (дата обращения: 23.12.2018).

5 Armenia's Parliamentary Debate. CivilNet. URL: https://www.civilnet.am/live/C907_SyKkil/494 (дата обращения: 23.12.2018).
} 


\section{Выводы}

Досрочные парламентские выборы 2018 г. в Армении обозначили окончание доминирования Республиканской партии Армении и приход к власти новой политической силы - блока «Им кайл» («Мой шаг»). Тем не менее стабильность политических институтов в стране может быть подвергнута сомнению, как и длительность существования новоизбранного парламента. В ситуации поляризации политического поля можно ожидать попытки вернуть власть или оспорить преимущество блока.

Повестка блока «Им кайл» до сих пор строится на осуждении прежнего политического режима, инициировании крупных антикоррупционных дел, обещаниях о повышении зарплат и социальных выплат за счёт борьбы с монополизацией экономики. В скором времени блок столкнется с необходимостью поиска долгосрочных источников роста экономики.

По-прежнему одним из ключевых вопросов внутренней политической дискуссии Армении остаётся ситуация в Нагорном Карабахе. Однако какие-либо подвижки в решении конфликта маловероятны: пришедшие к власти политические силы скорее склонны к бескомпромиссной позиции.

\section{Список литературы}

Armenia's Parliamentary Debate. CivilNet. URL: https://www.civilnet.am/live/ C907_SyKkiI/494 (дата обращения: 23.12.2018).

December 09, 2018 Parliamentary Elections. Central Electoral Commission. URL: https://www.elections.am/parliamentary/ (дата обращения: 23.12.2018).

Бывший соратник Пашиняна будет в парламенте единственной оппозицией. REGNUM. URL: https://regnum.ru/news/2534947.html (дата обращения: 23.12.2018).

Пашинян анонсировал пополнение бюджета Армении деньгами олигархов. Кавказский узел. URL: https://www.kavkaz-uzel.eu/articles/328518/ (дата обращения: 23.12.2018).

Пашинян пообещал повысить зарплаты. News.am. URL: https://news.am/rus/news/483580.html (дата обращения: 23.12.2018).

Sluunt u n L קJ n L l . Civic Contract. URL: https://civilcontract.am/party-program/tntesowtyown (дата обращения: 23.12.2018).

Пашинян и Путин пока не смогли договориться о цене на российский газ. REGNUM. https://regnum.ru/news/2537590.html (дата обращения: 23.12.2018).

\section{Parliamentary Elections in Armenia: Perspectives of «My Step» Alliance}

Author. Anna Ayvazyan, Research Associate, Institute of Europe, Russian Academy of Sciences. Address: 11-3, Mokhovaya str., Moscow, Russia, 125009. E-mail: anna.ayvazyan@ gmail.com.

Abstract. On 9 December, 2018 snap parliamentary elections took place in Armenia that have put an end to the change of political elite process started in April. As a result, the dominant Republican Party of Armenia has become an opposition force not presented in the current parliament. The victory was taken over by the «My step» alliance, founded by the leader of mass protests Nikol Pashinyan. The political transformation that happened in Armenia has, nevertheless, made the issues of political reforms, search for a long-term economic strategy and Nagorno-Karabakh problem more salient.

Key words: Armenia, parliamentary elections.

DOI: http://dx.doi.org/10.15211/vestnikieran620186164

Научно-аналитический вестник ИЕ РАН, 2018, №6 